\title{
Penerapan Database pada Perusahaan (Studi Penerapan ERP pada PT. Sinar Sosro)
}

\author{
Dina Marlina Sagala1, Lesty Rahmadani², Yulia Rahmadani ${ }^{3}$, Endang Sri \\ Wahyuningsih ${ }^{4}$, Auliyah Arifah ${ }^{5}$,Nadia Fathurrahmi Lawita ${ }^{6}$ \\ ${ }^{12345}$ Program Studi Akuntansi, Fakultas Ekonomi dan Bisnis, Universitas Muhammadiyah \\ Riau \\ E-mail: 180301324@student.umri.ac.id
}

\begin{abstract}
Abstrak
Penerapan Enterprise Resources Planning (ERP) PT. Sinar Sosro merupakan bagian dari strategi penguatan internal bisnis perusahaan dan pilihan yang cukup penting dalam konteks, karena tidak sedikit berbagai implementasi ERP oleh perusahaan-perusahaan di Indonesia yang mengalami kegagalan, baik disebabkan oleh over budget, over time dalam pengerjaan proyek, kinerja sistem yang kurang maupun keuntungan yang tidak sesuai harapan (Dantes \& Hasibuan, 2011). Pilihan investasi ERP ini bukan tanpa sebab, berbagai pengaruh lingkungan internal maupun eksternal telah menjadi dorongan tersendiri bagi PT. Sinar Sosro. Dalam tahap inisiasi, implementasi ERP dilakukan secara bertahap dimulai dengan modul SAP kemudian modul FICO (Financial Controlling) dengan memperhatikan kesiapan infrastruktur dan pengembangan aplikasi-aplikasi existing (in-house development) agar nantinya dapat diintegrasikan dengan basis data pada ERP.
\end{abstract}

Kata Kunci : Penerapan ERP, analisis ERP, pengembangan bisnis pada ERP

\begin{abstract}
The application Enterprise Resource Planning (ERP) at PT. Sinar Sosro is a part of strengthening internal business strategy and important options because there is many implementation of ERP by various companies in Indonesia that have failed either due to overbudget, over- time in construction project, the performance of the system is lacking and benefits that are not as expected (Dantes \& Hasibuan, 2011). ERP investment options is due without reasoning, many of internal and external environments that influence and drive the need of implementation ERP at PT. Sinar Sosro. In the initiation phase, ERP implementation is done in stages starting with the modules of SAP then modules of FICO ( Financial Controlling ) with regard infrastructure readiness and the development of existing applications (in-house development) that to be integrated with the ERP database.
\end{abstract}

Keywords : ERP Implementasi , ERP analysis, business development On ERP

\section{PENDAHULUAN}

Persaingan yang semakin ketat antar perusahaan menuntut suatu perusahaan untuk dapat meningkatkan kinerja perusahaan sebagai usaha peningkatan pelayanan terhadap stakeholder perusahaan. Salah satu hal yang diperlukan dalam peningkatan kinerja perusahaan adalah tersedianya data terintegrasi sehingga didapatkan informasi dengan cepat yang dibutuhkan oleh pengambil keputusan. Enterprise Resource Planning (ERP) merupakan suatu metode integrasi dari beberapa proses bisnis seperti aspek operasi, produksi maupun distribusi perusahaan. Penerapan ERP tidak terlepas dari timbulnya permasalahan baik yang disebabkan oleh faktor internal dan eksternal sehingga perlu dilakukan analisis faktor internal dan faktor eksternal yang berpengaruh terhadap keberhasilan ERP.

Untuk memasuki pasar internasional, ERP merupakan salah satu yang menjadi pra-syarat dasar bagi setiap perusahaan. Indonesia merupakan negara yang sedang berkembang, dimana basis perekonomiannya bertumpu di bidang bisnis, maka efisiensi menjadi salah satu faktor yang cukup penting dalam setiap perusahaan. Pada kenyataannya, masih didapati 
banyak perusahaan berskala besar yang masih kurang efisien contohnya saja dalam penerapan ERP yang merupakan salah satu cara untuk meningkatkan efisiensi perusahaan. Jika dilihat dari kondisi perusahaan-perusahaan di Indonesia, banyak perusahaan besar yang belum cukup optimal dalam mengintegrasikan setiap proses dalam perusahaan tersebut ke dalam suatu sistem komputerisasi.

PT. Sinar Sosro merupakan perusahaan minuman teh siap minum dalam kemasan botol yang pertama di Indonesia. Sebagai perusahaan yang bergerak di bidang produsen minuman, PT. Sinar Sosro memerlukan sistem yang dapat mengintegrasi seluruh data penting yang akan menghasilkan infomasi agar manajemen dapat menggunakan informasi tersebut untuk menghasilkan keputusan dengan cepat.

\section{METODE PENELITIAN}

Penelitian ini menggunakan jenis metode kualitatif, bertujuan agar dapat mendiskripsikan dengan jelas tentang "Penerapan ERP pada PT.Sinar Sosro".

Penelitian kualitatif adalah penelitian yang menghasilkan data deskriptif berupa ucapan,tulisan, atau perilaku dari obyek-obyek yang diteliti.Dengan demikian maka peneliti berusaha untuk memberikan pemaparan tentang segala sesuatu yang menjadi objek penelitian dalam bentuk deskriptif kalimat sesuai dengan keadaan sesungguhnya dari suatu objek. Penelitian yang bersifat deskriptif lebih tepat menggunakan apabila menggunakan penelitian kualitatif

\section{Profil PT. Sinar Sosro}

Tertulis dalam website-nya, PT. Sinar Sosro merupakan perusahaan minuman teh siap minum dalam kemasan botol yang pertama di Indonesia, yang berdiri pada tahun 1974. Nama Sosro diambil dari nama keluarga pendirinya yakni "Sosrodjojo". Pada tahun 1940, Keluarga Sosrodjojo memulai usahanya di sebuah kota kecil bernama Slawi di Jawa Tengah. Pada saat memulai bisnisnya, produk yang dijual adalah teh kering dengan merek Teh Cap Botol dimana daerah penyebarannya masih di seputar wilayah Jawa Tengah.

Kemudian di tahun 1953, Keluarga Sosrodjojo mulai memperluas bisnisnya dengan merambah ke ibukota Jakarta untuk memperkenalkan produk Teh Cap Botol yang sudah sangat terkenal di daerah Jawa Tengah. Perjalanan untuk memperkenalkan produk Teh Cap Botol ini dimulai dengan melakukan strategi Cicip Rasa (product sampling) ke beberapa pasar di kota Jakarta. Awalnya, datang ke pasar-pasar untuk memperkenalkan Teh Cap Botol dengan cara memasak dan menyeduh teh langsung di tempat. Setelah seduhan tersebut siap, teh tersebut dibagikan kepada orang-orang yang ada di pasar secara cuma-cuma. Tetapi cara ini kurang berhasil karena teh yang telah diseduh terlalu panas dan proses penyajiannya terlampau lama sehingga pengunjung di pasar yang ingin mencicipinya tidak sabar menunggu. Cara kedua, teh tidak lagi diseduh langsung di pasar, tetapi dimasukkan ke dalam panci - panci besar untuk selanjutnya dibawa ke pasar dengan menggunakan mobil bak terbuka. Lagi-lagi cara ini kurang berhasil, karena teh yang dibawa, sebagian besar tumpah dalam perjalanan dari kantor ke pasar. Hal ini disebabkan pada saat tersebut jalanan di kota Jakarta masih berlubang dan belum sebagus sekarang. Akhirnya ditempuh cara lain, yaitu air teh yang telah diseduh dikantor kemudian ditaruh di dalam botol-botol bekas limun/kecap yang telah dibersihkan terlebih dahulu untuk selanjutnya dibawa ke tempat-tempat kegiatan promosi Cicip Rasa berlangsung. Ternyata cara ini cukup menarik minat pengunjung karena selain praktis juga bisa langsung dikonsumsi tanpa perlu menunggu tehnya dimasak seperti cara sebelumnya.

Pada tahun 1969 muncul gagasan untuk menjual teh siap minum (ready to drink tea) dalam kemasan botol dengan merek "Teh Botol Sosro". Merek tersebut dipakai untuk mendompleng merek Teh Seduh Cap Botol yang sudah lebih dulu populer dan mengambil bagian dari nama belakang Keluarga Sosrodjojo. Untuk kemunculan desain botol pertama, adalah pada tahun 1969 dan desain botol tidak berubah, lebih dari 2 tahun. Untuk desain botol kedua yaitu pada tahun 1972 juga bertahan selama 2 tahun. 
Dan pada tahun 1974, dengan didirikannya pabrik pertama PT. Sinar Sosro di kawasan Menteng (saat itu masuk wilayah Bekasi, namun sekarang berada di wilayah Jakarta), maka desain botol Teh Botol Sosro berubah dan bertahan sampai sekarang. Pabrik tersebut juga merupakan pabrik teh siap minum dalam kemasan botol pertama di Indonesia dan di dunia.
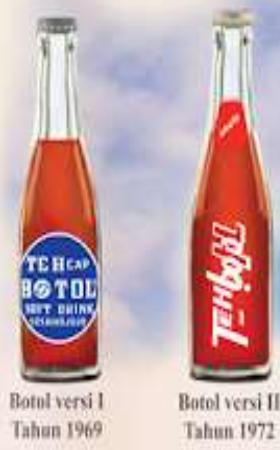

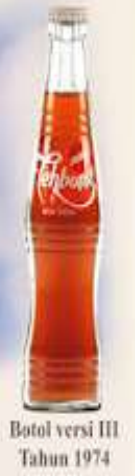

Perubahan Bentuk Botol dan Logo Teh botol Sosro.

\section{Struktur Organisasi PT. Sinar Sosro}

Struktur organisasi PT. Sinar Sosro berbentuk gabungan lini dan fungsional dimana kebijakan dan wewenang diberikan oleh pimpinan kepada bawahan sesuai dengan tugas dan tanggung jawab masing-masing. Dengan pimpinan setiap departemen dapat memberikan perintah kepada semua staf dan anggota yang ada sesuai dengan bidang kerjanya.

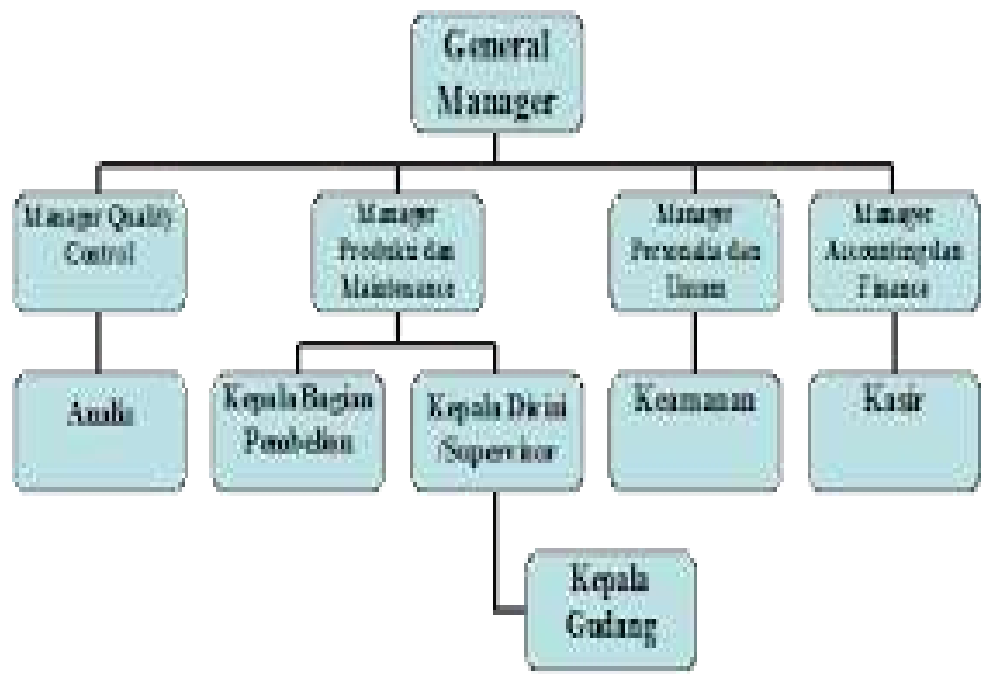

Pembagian pekerjaan pada PT. Sinar Sosro dibagi menurut fungsi yang telah ditetapkan. Setiap personil diberikan tugas dan tanggung jawab sesuai dengan dasar kualifikasinya. Adapun tugas dan tanggung jawab serta wewenang di PT. Sinar Sosro (Nanda, 2013) adalah sebagai berikut:

- General Manager

Merupakan pimpinan tertinggi perusahaan yang bertanggung jawab kepada Direktur Operasi. Tugasnya sebagai berikut:

(1) Menentukan garis kebijakan umum dari program kerja perusahaan.

(2) Bertanggung jawab ke dalam dan ke luar perusahaan.

(3) Mengarahkan dan meneliti kegiatan perusahaan.

(4) Menerapkan, menyebarkan kebijakan serta mengawasi pelaksanaannya.

(5) Melaksanakan kontrak kerja dengan pihak luar.

(6) Bersama manager lain membuat rencana produksi per triwulan. 


\section{- Manager Quality Control}

Bertanggung jawab kepada General Manager. Tugasnya adalah sebagai berikut:

(1) Mengkoordinir dan mengawasi pengendalian mutu produk.

(2) Memberi saran-saran kepada kepala bagian produksi mengenai mutu produk dan keadaan mesin/peralatan yang digunakan dalam proses produksi.

- Manajer Produksi dan Maintenance

Bertanggung jawab kepada General Manager. Tugasnya sebagai berikut:

(1) Merencanakan dan mengatur jadwal produksi produk agar tidak terjadi kekurangan dan kelebihan persediaan.

(2) Mengadakan pengendalian produksi agar produk sesuai dengan spesifikasi dan standar mutu yang ditentukan.

(3) Membuat laporan produksi secara periodik untuk mengenai pamakaian bahan dan jumlah produksi.

(4) Mengawasi dan mengevaluasi kegiatan produksi untuk mengetahui kekurangan dan ada penyimpangan sehingga dapat dilakukan perbaikan.

(5) Mengatur kegiatan perawatan mesin.

(6) Membuat rencana produksi sesuai dengan permintaan pemasaran.

- Manager Accounting and Finance

Bertanggung jawab kepada General Manager. Tugasnya sebagai berikut:

(1) Membuat laporan keuangan kepada atasan secara berkala tentang penggunaan uang.

(2) Mengendalikan budget pendapatan dari belanja perusahaan sesuai dengan hasil yang diharapkan.

(3) Bertanggung jawab atas penentuan biaya perusahaan seperti biaya administrasi.

- Kepala Bagian

Bertanggung jawab kepada Manajer Produksi dan PM. Tugasnya adalah sebagai berikut:

(1) Mengkoordinir dan mengawasi pelaksanaan kegiatan pembelian.

(2) Mengawasi kegiatan administrasi pembelian.

(3) Melakukan pembelian barang yang diminta oleh departemen lain.

- Analisis

Bertanggung jawab kepada manajer QC. Tugasnya adalah sebagai berikut:

(1) Melakukan pengukuran mutu produk baik sebelum diproses maupun setelah diproses.

(2) Memberikan saran dan langkah berikutnya yang dilakukan atas pengukuran mutu.

- Keamanan

Bertanggung jawab kepada Supervisor Personalia dan Umum. Tugasnya adalah Mengawasi dan mencatat tamu yang berkunjung ke perusahaan dan juga menjaga perusahaan setiap hari.

\section{Sejarah ERP}

ERP berkembang dari Manufacturing Resource Planning (MRP II), dimana MRP II sendiri adalah hasil evolusi dari Material Requirement Planning (MRP) yang berkembang sebelumnya. Sistem ERP secara modular biasanya menangani proses manufaktur, logistik, distribusi, persediaan (inventory), pengapalan, invoice dan akunting perusahaan. Ini berarti bahwa sistem ini nanti akan membantu mengontrol aktivitas bisnis seperti penjualan, pengiriman, produksi, manajemen persediaan, manajemen kualitas dan sumber daya manusia.

Tahapan Evolusi ERP :

- Tahap I : Material Requirement Planning (MRP), merupakan cikal bakal dari ERP, dengan konsep perencanaan kebutuhan material.

- Tahap II : Close-Loop MRP, merupakan sederetan fungsi dan tidak hanya terbatas pada MRP, terdiri atas alat bantu penyesuaian masalah prioritas dan adanya rencana yang dapat diubah atau di ganti jika diperlukan. 
- Tahap III : MRP-II, merupakan pengembangan dari close-loop MRP yang ditambahkan 3 elemen yaitu: perencanaan penjualan dan operasi, antarmuka keuangan, dan simulasi analisis dari kebutuhan yang diperlukan

- Tahap IV : ERP, merupakan perluasan dari MRP II yaitu perluasan pada beberapa proses bisnis diantaranya integrasi keuangan, rantai pasok dan meliputi lintas batas fungsi organisasi dan juga perusahaan dengan dilakukan secara mudah.

- Tahap V : Extended ERP (ERP II), merupakan perkembangan dari ERP yang diluncurkan thn 2000, serta lebih komplek dari ERP sebelumnya.

Dalam penerapan ERP, sekitar 10\%-40\% dari penggunaannya mengalami kegagalan. Untuk mengatasinya ada beberapa hal penting yang harus dilakukan supaya penerapan ERP berhasil, diantaranya adalah sebagai berikut.

1. Pemahaman yang jelas ata sasaran strategis perusahaan.

2. Komitmen dari seluruh jajaran manajemen.

3. Manajemen implementasi proyek yang baik.

4. Mampu mengatasi isu-isu teknik.

5. Tim implementasi yang baik.

6. Rekayasa ulang proses bisns.

7. Komitmen organisasi untuk berubah.

8. Pendidikan dan pelatihan yang intensif.

9. Data yang akurat.

10. Sosialisasi dan komunikasi yang intensif.

11. Pengukuran kinerja yang jelas fokusnya.

Kelebihan yang dimiliki ERP diantaranya adalah :

1. Menghindari input data yang sama berkali-kali sehingga lebih efisien.

2. Mempercepat waktu pemrosesan data, meminimalisasi proses penarikan dan penampilan data.

3. Kemudahan adaptasi, proses perubahan bisnis dapat diatasi dengan mudah.

4. Kemudahan pemeliharaan, dukungan purnajual sistem yang berjangka panjang.

5. E-commerce, membuka akses ke internet dan kultur kerjasama yang lebih mudah.

Namun, ERP juga memiliki beberapa kelemahan, yaitu :

1. Mahal, biaya bervariasi dari ribuan sampai jutaan dollar.

2. Kesesuaian modul, arsitektur dan komponen dari sistem yang dipilih harus sesuai dengan proses bisnis, kultur dan sasaran strategis organisasi.

3. Ketergantungan pada satu vendor tertentu, memerlukan support jangka panjang dari vendor.

4. Kompleksitas, sistem ERP biasanya memiliki terlalu banyak fitur dan terlalu kompleks.

5. Risiko kerugian tinggi bila sistem informasi diambil/di-hack oleh pihak yang tidak bertanggung jawab.

ERP yang digunakan PT. Sinar Sosro adalah Oracle ERP. Oracle adalah basis data relasional yang terdiri dari kumpulan data dalam suatu sistem manajemen basis data RDBMS (Relational Database Management System). Perusahaan perangkat lunak Oracle pertama kali dikembangkan pada tahun 1977 dan hingga saat ini Oracle memasarkan jenis basis data yang dapat digunakan pada berbagai jenis dan merk platform seperti Mac, LINUX dan Windows.

Kelebihan dari Oracle ERP adalah :

1. Oracle bekerja di jaringan komputer. Oracle memisahkan proses antara database server dan aplikasi client. Server yang terinstal Oracle bertangungjawab menangani proses database, sementara client/workstation yang menjalankan aplikasi hanya berkonsentrasi menampilkan data. Struktur ini akan mengurangai kemacetan jaringan.

2. Oracle mendukung ukuran database yang sangat besar hingga jumlahnya terabyte. Oracle juga mendukung pengaturan penggunaan space pada harddisk sehingga ruangan harddisk termanfaatkan secara efisien.

3. Oracle mendukung pelayanan multiuser yang terkoneksi pada waktu yang sama dan mengakses data yang sama serta mengatur sistem agar pemrosesan data dapat 
berjalan dengan cepat walaupun jumlah transaksi sangat banyak pada waktu yang hampir bersamaan karena Oracle dapat menggunakan berbagai sistem operasi dalam suatu jaringan untuk mengakses data. Dengan fasilitas ini, Oracle mampu menghindari konflik data dengan baik. Selain itu Oracle dapat menjalankan database selama 24 jam dalam sehari sehingga pemisahan iystem komputer dan proses backup dapat dilakukan secara online tanpa harus mematikan database.

4. Oracle memiliki fitur yang baik untuk membatasi dan dan memonitor akses data sehingga dapat menghindari akses database dari pihak-pihak yang tidak berkepentingan. Kontrol untuk mengendalikan data tersebut dapat mengendalikan data dari manapun sehingga tidak perlu membuat kode di banyak aplikasi, cukup di satu database Oracle saja.

5. Oracle dapat berjalan di berbagai sistem operasi dan aplikasi yang menggunakan data Oracle dapat dengan mudah megakses data Oracle yang berjalan di system apapun.

6. Oracle dapat memisahkan database-nya dalam komputer-komputer yang secara fisik terpisah namun secara logis terlihat seperti satu database.

Oracle sangat membantu dalam proses pembuatan Teh Botol Sosro dengan menampilkan beberapa varian yang di peroleh dengan menggunakan ERP. Dengan ERP ini, juga proses pengerjaannya ,menjadi lebih cepat dan praktis dan juga mudah untuk dilakukan. Sehingga PT. Sinar Sosro ini menerapkan ERP tersebut agar menghasilkan produk yang murah dan juga terjangkau baik kalangan bawah maupun yang sederhana.

\section{Penerapan ERP Pada PT. Sinar Sosro}

"Kami sungguh merasakan berbagai bentuk efisiensi setelah melakukan komputerisasi dengan pendekatan ERP," kata Hugo Winanto, Manajer Teknologi Informasi PT. Sinar Sosro, yang terkenal dengan produk Teh Botol Sosro. Winanto mengaku perusahaan itu sudah merancang untuk mengintegrasikan sistem komputernya sejak tahun 1999. Semula, menurutnya, ada dua jaringan komputer terpisah, yakni jaringan komputer unit produksi, dan jaringan komputer unit distribusi. Dua jaringan tersebut terpisah karena pada mulanya keduanya adalah unit bisnis yang memang terpisah. Saat ini, PT. Sinar Sosro sedang menangani proses integrasi jaringan komputer seluruh unit kerja perusahaan itu. Perlu diketahui, PT. Sinar Sosro memiliki 8 pabrik, 9 kantor cabang besar, dan lebih dari 100 stockist, sehingga perlu mengintegrasikan komputer yang tersebar disekitar 140 unit kerja yang berbeda tersebut.

Dalam waktu dekat, menurutnya, seluruh 140 unit kerja itu sudah akan tergabung dalam satu sistem yang terintegrasi menggunakan database dan aplikasi yang disediakan oleh Oracle. Walaupun proses integrasi antara unit produksi dengan unit distribusi belum sepenuhnya tuntas, Winanto mengaku manajemen sudah mendapatkan banyak sekali manfaat dari sistem online yang sudah berhasil dicapai di masing-masing jalur. Dulu misalnya, perlu waktu yang sangat lama untuk mendapatkan berbagai data terbaru perusahaan, misalnya data produksi, data stok barang atau data penjualan. Kelambatan itu terjadi karena seluruh proses pengumpulan data dilakukan secara manual. Tetapi dengan sistem online semuanya berubah. Sekarang kantor pusat sudah bisa mendapatkan data penjualan, data produksi, sampai dengan stok barang terbaru. Hal tersebut bisa terjadi karena hanya diperlukan satu kali proses input data, dan seluruh proses konsolidasi dilakukan oleh komputer.

Integrasi ini, menurut Winanto, telah mendongkrak efisiensi perusahaan secara signifikan. Kesalahan manusia (human error) dalam proses konsolidasi data kini bisa diabaikan. Jumlah tenaga kerja sudah bisa dikurangi, dan kini sejumlah staf sudah dialihkan untuk bidang kerja yang lain. "Dan yang pasti, walaupun belum bisa paperless, tetapi pasti sudah less paper dalam manajemen perusahaan."

Dengan luasnya penyebaran unit kerja PT. Sinar Sosro, diperlukan satu sistem jaringan yang sangat luas (Wide Area Network, WAN), dan untuk itu diperlukan layanan pihak ketiga untuk menyediakan layanan komunikasi data untuk tujuan tersebut. Untuk layanan tersebut, 
PT. Sinar Sosro mempercayakan pada PT. Lintasarta Aplikanusa, perusahaan yang sudah puluhan tahun berkecimpung dalam bisnis layanan komunikasi data.

Ketika ditanya mengenai kualitas layanan Lintasarta, Winanto mengatakan bahwa pihaknya cukup puas. Hal ini terbukti dari PT. Sinar Sosro yang sudah menggunakan layanan Lintasarta sejak 1999. Oleh sebab itu, ketika PT. Sinar Sosro berencana untuk memperluas jaringan, perusahaan tersebut akan mempercayakannya kepada Lintasarta.

Saat ini Sinar Sosro menggunakan layanan Frame Relay untuk mengintegrasikan sistem komputernya, tetapi perusahaan itu tengah mempertimbangkan untuk menggunakan teknologi jaringan virtual privat berbasis internet (VPN IP) yang juga ditawarkan oleh Lintasarta. berikut.

Tujuan dari penggunaan ERP bagi PT. Sinar Sosro (Ning, 2012), adalah sebagai

1. Mengantisipasi agar pertumbuhan perusahaan terus berkembang.

2. Menyajikan data yang konsisten dan akurat sehingga meningkatkan visibilitas bisnis dan kemudahan dalam pengambilan keputusan.

3. Mengintegrasikan informasi di antara kantor dalam jaringan PT. Sinar Sosro.

4. Mempermudah dalam fungsi akuntasi perusahaan.

5. Memperkecil human error dalam proses konsilidasi.

\section{Pengembangan Aktivitas}

Salah satu produk unggulan PT. Sinar Sosro adalah Teh Botol Sosro kemasan botol beling atau sering disebut RGB (Returnable Glass Bottle). Teh Botol Sosro kemasan botol beling merupakan produk teh siap minum yang pertama di Indonesia yang sudah diluncurkan sejak Tahun 1974. Untuk memenuhi kebutuhan pecintanya dimana pun berada, Teh Botol Sosro dengan inovasinya sampai dengan tahun 2008 telah memiliki banyak pilihan kemasan produk yaitu :

- Kemasan botol beling (Returnable Glass Bottle) dengan volume $220 \mathrm{ml}$.

- Kemasan kotak (Tetra Pak) dengan volume 1 liter, $250 \mathrm{ml}, 200 \mathrm{ml}$.

- Kemasan pouch dengan volume $230 \mathrm{ml}$.

Inovasi terbaru dari produk Teh Botol Sosro adalah Teh botol Sosro Less Sugar yang telah diluncurkan pada tanggal 20 Agustus 2008. Produk ini tersedia dalam kemasan PET volume $500 \mathrm{ml}$ dan kemasan kotak (Tetra Pak) volume $250 \mathrm{ml}$.

Produk Teh Botol Sosro, terbuat dari seduhan Teh Wangi Melati, di filter dan dicampur dengan sirup gula cair yang diperoleh dengan melarutkan gula pasir putih dan di proses secara higenis dan juga dengan tenaga kerja yang produktif sehingga dapat menghasilkan teh botol yang sesuai dengan citra rasa Indonesia.

\section{Komponen Sumber Daya Sistem PT. Sinar Sosro Sumber Daya Manusia}

Tidak banyak produk Indonesia yang begitu membanggakan dan mampu "menghajar" kekuatan kapitalis internasional. PT. Sinar Sosro merupakan salah satu perusahaan yang berhasil mengharumkan nama Indonesia dengan produk andalan mereka yaitu Teh Botol Sosro. Kesukseran Sosro dalam merebut hati konsumen Indonesia dapat dilihat dari aspek pemasaran yang cukup unik. Sosro, dalam beberapa hal, telah mengabaikan hukum-hukum umum yang terdapat dalam ilmu pemasaran.

Misalnya saja mengenai perlunya riset pasar sebelum meluncurkan produk. Konon kabarnya sebelum Sosro hadir, ada sebuah perusahaan asing yang ingin mengeluarkan produk teh dalam botol seperti yang dilakukan Sosro saat ini. Kala itu, pemilik perusahaan tersebut menyewa jasa sebuah biro riset pemasaran untuk menguji kelayakan dan prospek produk tersebut di Indonesia.

Setelah meneliti dan mengamati kebiasaan minm teh masyarakat Indonesia, sang biro pun menyimpulkan bahwa produknya tidak memiliki prospek bagus untuk dipasarkan di Indonesia. Biro itu beralasan bahwa budaya minun teh pada bangsa Indonesia umumnya dilakukan saat pagi hari dalam cangkir yang disajikan hangat. Sehingga kehadiran teh dalam 
kemasan botol justru akan dianggap sebuah varian yang sukses menarik perhatian masyarakat sebab ada hal tertentu yang mereka rasakan.

Sosrodjojo, pendiri perusahaan Sosro, justru berpikir sebaliknya. Awalnya ide kemasan botol berasal dari pengalaman tes cicip rasa (on place test) di pasar-pasar tradisional terhadap teh tubruk cap botol. Pada demonstrasi pertama teh langsung diseduh di tempat dan disajikan pada calon konsumen yang menyaksikan. Namun cara tersebut memakan waktu lama sehingga calon konsumen cenderung sudah meninggalkan tempatnya ketika teh telah siap untuk disaji. Kemudian pada uji berikutnya teh telah diseduh dari pabrik dan kemudian dimasukkan ke dalam tong-tong dan dibawa dengan mobil. Akan tetapi cara ini ternyata membuat banyak teh tumpah selama perjalanan karena saat itu struktur jalan belum sebaik sekarang. Akhirnya PT. Sinar Sosro mencoba untuk memasukkannya pada kemasankemasan botol limun agar mudah dibawa. Berangkat dari itu mereka berpikir bahwa penggunaan kemasan botol adalah alternatif yang paling praktis dalam menghadirkan kenikmatan teh langsung ke konsumen.

Dari awal produk ini ditargetkan untuk konsumen yang sering melakukan perjalanan seperti supir dan pejalan kaki. Sosro menyadari bahwa segmen konsumen ini memiliki keinginan hadirnya minuman yang dapat menghilangkan dahaga di tengah kelelahan dan kondisi panas selama perjalanan. Untuk menambah nilai kepuasan, teh botol ini disajikan dingin dengan menyediakan boks-boks es pada titik-titik penjualannya (penggunaan kulkas pada saat itu belum lazim). Tentu saja merubah kebiasaan tak semudah membalik telapak tangan. Pada masa-masa awal peluncurannya, Teh Botol Sosro tidak banyak dilirik oleh konsumen. Mereka justru menganggap aneh produk ini karena kemasan botol dan penyajian dinginnya. Namun sosro tidak patah semangat. Perusahaan ini terus mengedukasi pasarnya melalui iklan-iklan di berbagai media dan promosi-promosi on the spot. Perlahan, produk Teh Botol Sosro mulai mendapatkan tempat di hati konsumen Indonesia. Terlebih ketika slogan "Apapun makannya, minumnya Teh Botol Sosro" di munculkan. Slogan ini tidak saja mengguncang sesama produk teh namun juga produk minuman secara keseluruhan.

Sedikit kisah sukses Sosro itu memberikan pelajaran betapa pemasaran tidak hanya sekedar ilmu yang ekstra. Faktor knowledge terkadang hanya memberi kontribusi kecil pada kesuksesan produk ketika dipasarkan. Faktor sisanya adalah seni dan intuisi yang dapat memandu para pemasar mencapai hasil yang di luar dugaan. Gabungan antara ketiganyalah yang dapat menghasilkan seorang pemasar yang jenius dan berpikir di luar kebiasaan (Adya dkk, 2012).

Untuk itu, seorang pemasar yang jenius dan berpikir di luar kebiasaan harus memiliki kedisiplinan dalam bekerja. Sehingga dapat mengantarkannya untuk mencapai kepuasan kerja yang berpengaruh dalam kinerjanya (Lawita, 2020).

\section{Sumber Daya Jaringan}

Ketersediaan data dan informasi terbaru sumber daya perusahaan secara cepat dan sistematis akan sangat memudahkan dalam proses pengambilan keputusan oleh pihak manajemen. Diperlukan pilihan teknologi yang tepat sehingga efisiensi perusahaan bisa terpacu. Perlu mempertimbangkan penerapan sistem perencanaan sumber daya yang secara teknis disebut Enterprise Resource Planning (ERP). Teknologi ERP dapat mengintegrasikan fungsi pemasaran, produksi, logistik, keuangan, SDM, dan fungsi lainnya (Baheshti, 2006).

ERP telah berkembang sebagai alat integrasi, yang memiliki tujuan untuk mengintegrasikan semua aplikasi perusahaan ke pusat penyimpanan data dan dengan mudah diakses oleh semua bagian yang membutuhkan sehingga menghasilkan efisiensi yang tinggi bagi perusahaan (Sabana, 2002). Menurut Leon (2005) sebagaimana juga diungkapkan oleh Genoulaz \& Millet (2006), integrasi data pada teknologi ERP dilakukan dengan single data entry yakni sebuah departemen yang berfungsi memasukkan data, maka data tersebut dapat digunakan oleh fungsi-fungsi lain dalam perusahaan. 
Saat ini PT. Sinar Sosro telah memiliki 12 pabrik yang tersebut di beberapa wilayah Nusantara, yakni Medan, Palembang, Jakarta, Tambun, Cibitung, Ungaran, Gresik, Mojokerto, dan Gianyar. Serta pabrik yang khusus memproduksi air mineral, yaitu Prim-A, berada di Sentul, Purbalingga, dan Pandaan.

Seiring dengan kemajuan Teknologi Sistem Informasi Geografis atau disingkat SIG berbasis teknologi digital, terdapat banyak hal yang bisa dikembangkan lebih baik dari sebelumnya. Berkaitan dengan SIG yang didukung oleh kemajuan di dalam sistem pemetaan yang dulunya dikenal berupa peta kertas atau peta gambar hasil proses scanning (raster map) berkembang menjadi peta digital (digital map) yang di dalamnya bisa ditambahkan informasi lain yang terkait dengan geografi seperti informasi demografi, pendapatan per kapita, jaringan infrastruktur jalan sebagai akses distribusi, dan lain-lain. Informasi informasi ini disimpan terintegrasi dengan peta digital untuk bahan simulasi/manipulasi dalam perancangan operasi distribusi, dan dapat ditampilkan setiap saat sesuai keinginan.

\section{Sumber Daya Software}

Cetak biru implementasi TI, khususnya dalam pemanfaatan solusi ERP di Sosro disiapkan sejak tahun 1999 dan mulai diterapkan pada tahun 2000. Targetnya, pada tahun 2005 bagian produksi dan distribusi harus sudah on-line. Sistem ERP yang dibangun manajemen Sosro ini juga memungkinkan akses data dari kantor cabang Sosro di luar negeri. Setelah penerapan solusi ERP, banyak perubahan mendasar yang terjadi di tingkatan operasi dan administrasi. Meski kebutuhannya berbeda dengan dimana ERP harus mampu memenuhinya, satu syarat yang tidak dapat ditawar-tawar lagi adalah terintegrasi, yang menggabungkan berbagai kebutuhan pada satu software dalam satu logical database, sehingga memudahkan semua departemen dalam berbagi informasi dan berkomunikasi. Sebagai contoh, order penjualan yang dicatat di departemen penjualan akan secara otomatis diketahui kapan harus dikirim oleh bagian gudang. Begitu juga, bagian keuangan akan mengetahui kapan kas akan masuk dari pelanggan. Berkurangnya jumlah barang di gudang secara otomatis akan diketahui pula oleh bagian perencanaan produksi. Jika jumlah barang mencapai kondisi tertentu, sistem akan membuat permintaan produksi. Saat itu, informasi mengenai bahan baku yang dibutuhkan telah pula disajikan oleh sistem. Setelah bagian perencanaan produksi me-review informasi dan menyetujuinya, secara otomatis informasi akan mengalir ke bagian pembelian, yang memungkinkannya untuk menghubungi pemasok untuk negosiasi harga dan pengiriman. Saat itu, bagian pembelian juga mendapatkan berbagai informasi mengenai kinerja para pemasoknya. Setelah kesepakatan diperoleh, order pembelian dibuat dengan menekan satu tombol dan informasi rencana kedatangan barang telah sampai di bagian penerimaan barang. Sementara itu, bagian keuangan akan memperoleh informasi berapa jumlah uang yang harus disiapkan untuk order pembelian. Demikian dengan seterusnya, sehingga keseluruhan alur proses bisnis di perusahaan tersebut menjadi sangat efisien. Perubahan-perubahan yang terjadi di satu bagian dapat diantisipasi dengan baik oleh bagian terkait lainnya. 2008):

Poin-poin yang bisa digunakan sebagai pedoman pada saat implementasi ERP (Dhika,

- ERP adalah bagian dari infrastruktur perusahaan, dan sangat penting untuk kelangsungan hidup perusahaan. Semua orang dan bagian yang akan terpengaruh oleh adanya ERP harus terlibat dan memberikan dukungan.

- ERP ada untuk mendukung fungsi bisnis dan meningkatkan produktivitas, bukan sebaliknya. Tujuan implementasi ERP adalah untuk meningkatkan daya saing perusahaan.

- Pelajari kesuksesan dan kegagalan yang terdapat dalam implementasi ERP, jangan berusaha membuat praktik ERP. Terdapat metodologi tertentu untuk implementasi ERP yang lebih terjamin keberhasilannya. 


\section{SIMPULAN}

PT. Sinar Sosro merupakan salah satu perusahaan agribisnis di Indonesia yang menggunakan ERP dalam menanajemen perusahaannya. Sistem ERP yang dibangun manajemen Sosro ini memungkinkan akses data dari kantor cabang Sosro di luar negeri. Fungsional area pada PT. Sinar Sosro meliputi: penjualan dan pemasaran, manufaktur, keuangan, akutansi, logistik, distribisi, persediaan (inventory), invoice.

ERP yang digunakan PT. Sinar Sosro adalah Oracle ERP. PT. Sinar Sosro menggunakan ERP bertujuan untuk mengantisipasi pertumbuhan perusahaan yang terus berkembang, menyajikan data yang konsisten dan akurat sehingga meningkatkan visibilitas bisnis, kemudahan dalam pengambilan keputusan, mengintegrasikan informasi di antara kantor dalam jaringan PT. Sinar Sosro, mempermudah dalam fungsi akuntansi perusahaan, serta memperkecil human error dalam proses konsilidasi

Adapun manfaat yang diperoleh dalam penggunaan ERP pada PT. Sinar Sosro, yaitu meningkatkan efisiensi dalam proses bisnis misalnya dalam fungsi akuntansi yaitu mempermudah dalam tutup buku, mempermudah pengambilan keputusan bisnis, dikarenakan data yang selalu terupdate, akurat dan konsisten, efisiensi penggunaan jumlah pegawai, mempermudah kontrol perusahaan, dan penyeragaman kebijakan diantara semua unit bisnis perusahaan. ERP ini adalah salah satu database yang di percayakan PT. Sinar Sosro untuk melakukan pengoperasian agar produk teh yang dihasilkan baik untuk di konsumsi dan dapat memberikan rasa yang disukai.

\section{DAFTAR PUSTAKA}

Adya, Galih Damar dkk, Penerapan Sistem Informasi PT Sinar Sosro. Makalah.

Bahesthi, H.M., 2006, What Manager Should Know About ERP/ERP II, Management Research New. Vol. 29 No. 4, pp 184-193.

Dantes, and Hasibuan, 2011, The Impact of Enterprise Resource Planning (ERP) System Implementation on Organization: Case Study ERP Implementation in Indonesia, IBIMA Business Review, Vol. 2011. Diakses dari http://www.ibimapublishing.com/journals/IBIMABR/ibimabr

Dhika, Y.P., 2008, Deskripsi Enterprise Resource Planning (ERP). Diakses pada 20 Juli 2021, dari http://yonikasc-yonikasc.blogspot.com/

Genoulaz, V.B., and Millet, P.A., 2006, An Investigation into the Use of ERP System in the Service Sector, International Journal of Production Economics 99, pp. 202-221.

Lawita, Fathurrahmi Nadia dan Fitria, Lena, 2020, Faktor yang mempengaruhi Kinerja Karyawan Keuangan pada Perusahaan Ritel Melalui OCB sebagai Variabel Mediasi, Jurnal Akuntansi dan Ekonomika. Vol. 10 No. 1.

Leon, A., 2005, Enterprise Resource Planning, McGraw-Hill Publishing Company Limited, New Delhi.

Nanda, 2013, SDM dan Organisasi PT Sinar Sosro. Diakses pada 21 Juli 2021, dari http://nanda-bima.blogspot.co.id/2013/11/sdm-dan-organisasi-pt-sinar-sosro.html

Ning, Rusiyani Puspita, 2012, Penerapan Enterprise Resource Planning Pada PT. Sinar Sosro. Makalah.

Official Web PT. Sinar Sosro. Diakses pada tanggal 20 Juli 2021, dari www.sosro.com

Sabana, A., 2002 Enterprise Resource Planning di PT. Ultrajaya Milk Industry \& Trading Tbk. Warta Ekonomi.

Tarigan, Zeplin Jiwa Husada, 2011, Perancangan Penjualan dan Perencanaan Produksi yang Terintegrasi dengan Menerapkan Teknologi Enterprise Resources Planning (Studi Kasus pada Perusahaan Furniture, Consumer Good dan Elektronik), FTI UK Petra. Diakses pada 20 Juli 2021, dari http://onepieceoftruth.wordpress.com/2011/09/25/abrief-explanation-of-erp-enterprise-resource-planning-and-its-application/

Wicaksono, S., 2011, Enterprise Resource Planning: Definisi, penerapan, dan manfaatnya bagi perusahaan. Diakses pada 20 Juli 2021, dari http://onepieceoftruth.wordpress.com/2011/09/25/a-brief-explanation-of-erpenterprise-resource-planning-and-its-application/ 